condition, at $5^{\circ} \mathrm{C} \mathrm{pH} 9.0$.

\title{
References
}

1) Goldwasser, R. A. and Shepard, C.C., J. Immunol., 80, 122, $1958 . \quad$ 2) Goldstein, G., Spalding, B. H. and W. B. Hunt, Proc. Soc. Exp. Biol. Med., 111, 416, 1962 . 3) McDevitt, H. O., Peters, J. H., Pollard, L. W., Harter, J. G. and A. H. Coons, J. Immunol., 90, 634, 1963. 4) Marshal, J. D., Eveland, W. C. and Smith, C. W., Proc. Soc. Exp. Biol. Med., 98, 898, $1958 . \quad$ 5) Coons, A. H. and Kaplan, M. H., J. Exp. Med., 91, 1, 1950. 6) Bock, R. M. and Nan-Sing Ling, Anal. Biochem., 26, 1543, $1954 . \quad 7)$ Goldstein, G., Slizys, I.S. and Chase, M. W., J. Exp. Med., 114, 89, $1961 . \quad$ 8) Curtain, C. C., J. Histochem. Cytochem., 9, 484, 1961.

\section{Our Freeze-Substitution Method for Histochemical Studies}

\author{
Shunta Hirose, Hideo Mryajima, Masayuki Yasutomi, \\ Akio Kaname, Shunichi Uetsuki, \\ and Ryotaro Yamada \\ The 2nd Department of Surgery, Osaka University Medical School, Osaka, Japan
}

\section{Introduction}

It is neccesary, from the standpoint of histochemical investigations, that the suitable fixatives have to be selected according to the respective cellular substances and enzymes for obtaining the optimal reactions.

The troublesome thing in the present methods of fixations is that the tissue block was too small to study a number of reactions with one small tissue block. The study was undertaken in an attempt to get as many reactions as possible from the small tissue block using Freeze Substetution Method (FSM) devised by the present authors instead of various established methods of fixation. As the results, the adequate and excellent observations were obtained both morphologically and histochemically. FSM has been used mainly in morphological studies ${ }^{2-4)^{(13) 16}}$ as an expedient method of Freeze-Drying Method, and several authors described superiority of FSM in the histochemical observations ${ }^{(5)(15) 15}$, but the adequate examination of the correlation between morphological and histochemical enzymic details were scarcely carried out. FSM devised by the authors provides both reliable cytological observations and good preservations of the hydrolytic enzymes.

\section{Procedures}

Shortly after young male rat was sacrificed the liver was removed. Then the liver was cut $3 \mathrm{~mm}$ thick by razor blade and the liver tissue blocks were 
frozen rapidly in the test tube containing $-80^{\circ} \mathrm{C}$ pure acetone as quenching and dehydrating solvent which was cooled previously with dryice-acetone mixture in a wide mouth dewar flask. The temperature of the freezing mixture rose initially gradually and lately progressively following to vaporation of dryice (Fig. 1). When the temperature got to around $10^{\circ} \mathrm{C}$ a few days later, the specimens were transfered into pure acetone and kept at room temperature for about an hour. The specimens were embedded in low M.P. paraffin according to the usual method. About $2 \mathrm{~cm}$ above from the bottom of the test tube, which contained pure acetone as the dehydrating solvent, was compressed to become flat and stenotic. So, the test tube was divided into upper and lower parts by this stenotic part. The tissue specimens were placed on the upper part than this stenotic part and the solvent diluted with the dehydrated tissue water settled in the lower part than this stenotic part and the undiluted solvent constantly immersed all sides of the tissue blocks.

The Temperature of Substitution Medium

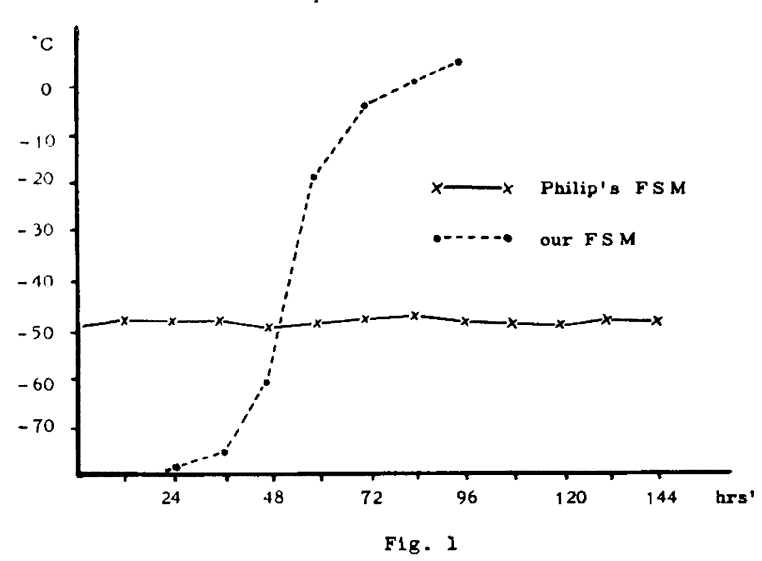

Morphological Examinations.

Generally speaking, satisfactory fixatives for preserving the subcellular organizations (i.e. chemical fixatives) used to show deststructive effects on the enzyme activities themselves. Besides, cold acetone fixation has been used most frequently for enzymatic studies, while it always led to destruction of the structures. Also in our experiments, cold acetone caused remarkable destruction of cell and tissue structures. FSM exceeded generally than other methods using other fixatives (for instance, cold acetone, alcohol, formalin and other various chemical fixatives) in retaining the well defined morphological structures. Substitution was commonly brought about around $-40^{\circ} \mathrm{C}$ for $48 \mathrm{hrs}-120 \mathrm{hrs}^{\left.2{ }^{9)}{ }^{13}\right)}$. It was found that morphological results by our method were comparable to that of substitution in $-40^{\circ} \mathrm{C}$ acetone for $120 \mathrm{hrs}$, which was obtained by utilizing Philip's apparatus ${ }^{12}$. In short, nuclear shapes and their membranes were preserved well, and there was no vacuolisation in nuclei and protoplasms.

Substitution in $-40^{\circ} \mathrm{C}$ acetone for $48 \mathrm{hrs}$, provided a fairly good results, 


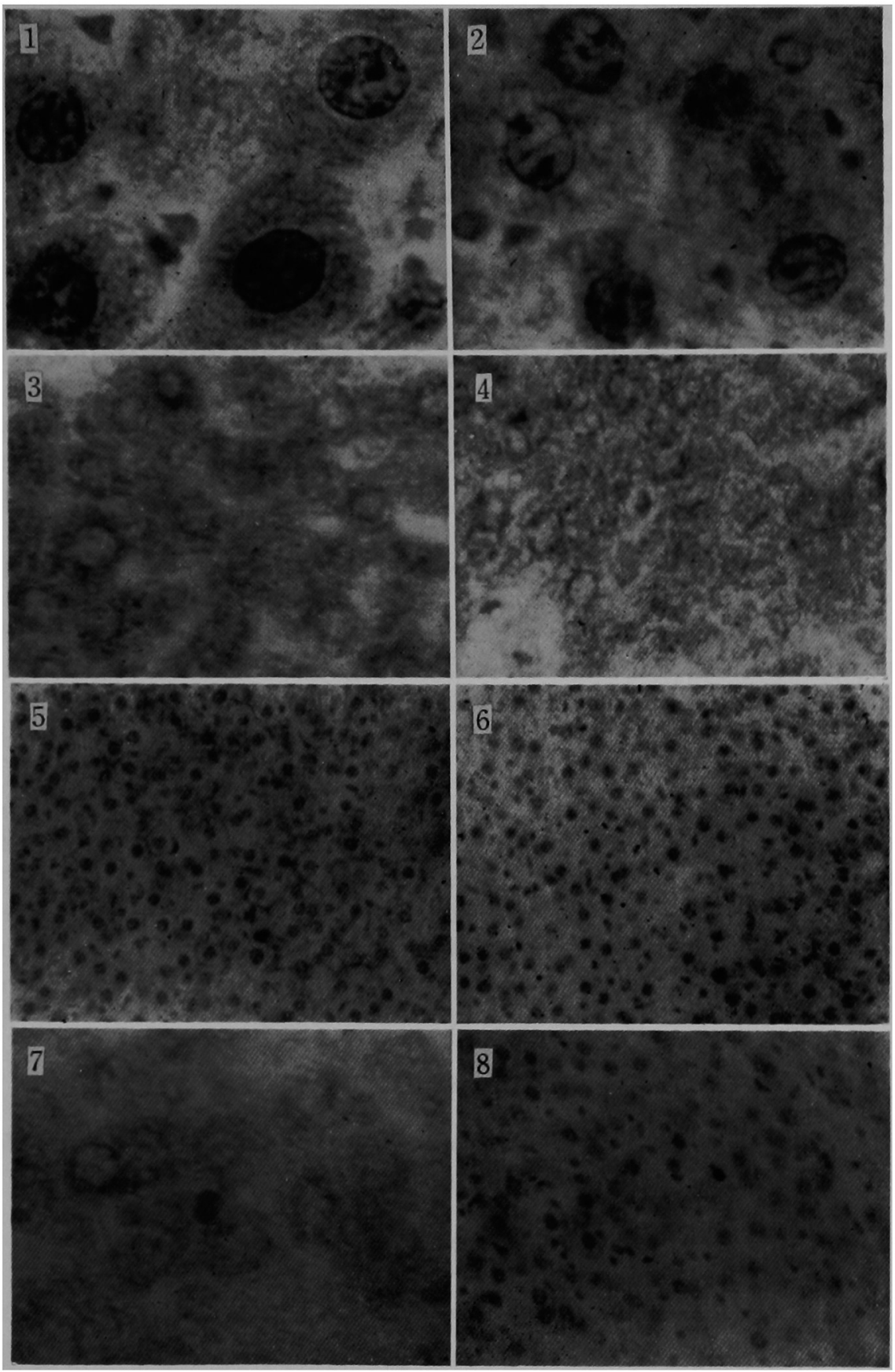

but this substitution was worse than both our method and one in $-40^{\circ} \mathrm{C}$ acetone for $120 \mathrm{hrs}$. Acetone was one of the most favorable substitueut, but alcohol caused a moderate distortion of tissue and cellular structures. Quenching in liquid nitrogen provided a good result, but showed occasionally partial split of tissue sections. Quenching in $-80^{\circ} \mathrm{C}$ acetone provided the 
satisfactory cytological observations. After the substitution, the tissue block was immersed in pure acetone for an hour at room temperature. The purposes of this immersion were to get the complete dehydration and to be able to observe somewhat denatured but well-preserved watersoluble components of the tissue in the following steps. Immersion in alcohol was not good to get morphological structures and several histochemicl reactions, because the dehydration and denaturation was too drastic.

\section{Histochemical Examinations}

As we described above, it was apparent that in the tissue treated by our method accurate morphological details were obtained.

Histochemical reactions were examined. In our frozen substituted tissues, excellent findings were obtained in RNA staining using pryonin-methylgreen, and were much superior than those of Carnoy's fixative which was used usually for RNA staining. The more substitution prolonged such as for 120 hrs. in $-40^{\circ} \mathrm{C}$, however, the more the staining substances decreased in spite of well morphological preservation.

In PAS staining for carbohydrate by Hotchkiss-McManus's method, PAS positive substances which were stained finely granulated, were not distributed polarised and coarsely, but uniforuly in protoplasm.

Several enzymes were studied with the tissue sections treated by the ordinary FSM, our new FSM and cold acetone fixation methods.

For example, alkaline phosphatase, acid phosphatase, lipase, esterase and phosphamidase were stained. In these histochemical examinations successful localizations were observed in the tissues treated by our FSM. Ordinary FSM using acetone as the substituent was found to reveal a fairly intense activity of enzymes, but the prolonged substitution decreased the activities of some enzymes. Not only as substitution medium but also as immersion one, alcohol inhibited or decreased the activities of some enzymes.

\section{Summary}

New FSM devised by ourselves was described. This method gave excellent observations in the morphological and histochemical examinations.

\section{References}

1) Altomann, R.: Die Elementarorganismen und ihre Beziehungen zur Zellen. Viet. \& Co. Leipzig, 1894. 2) Baud, C. A.: Bull. Micr. Appl. Ser., 2 : 158, $1952 . \quad 3)$ Bell, L.G.E.: In. Rev. Cytology, $1: 35,1952 . \quad 4)$ Blank, H. et al.: Stain Technol., $26: 193,1951$. 5) Burstone, M.S. : J. Histochem. Cytochem., $6: 322,1951 . \quad 6)$ Change, J. P. and Hori, S. H. : J. Histochem. Cytochem., $9: 292,1961 . \quad 7)$ Change, J. P. et al. Amer. J. Clin. Path., $35: 14.1961 . \quad 8)$ Feder, N. and Sidman, R. L.: J. Biochem. Biophys. Cytol., 4 : 593, 1958. 9) Hncox, N. J.: Exp. Cell. Res., $13: 263,1957 . \quad 10)$ Müller, H. and Szent-Györgyi, A.: Science, $126: 970,1957 . \quad 11)$ Pathen, S. F. : Lab. Invest. $7: 209,1958$. 12) Philip, S. W. and Pollister, A. W. : Stain Technol., $30: 123,1955 . \quad 13)$ Simpson, W. L. : Anat. Rec., $80: 173,1941 . \quad 14)$ Sugimoto, A. and Yegi, Tr. Soc. Path. Jap. $50: 193,1961$. 
15) Sugimoto, A., Proc. Jap. Histochem. Ass. $3: 55,1962 . \quad 16)$ Taft, E. B. : Stain. Technol., $26: 205,1951$.

\title{
Explanation of the plates.
}

1) Structure of the liver cells are well maintained. H. E. stain after our FSM (FSM A).

2) Structure of liver cells are partially destroyed. H. E. Stain after FSM in which the absolute alcohol was used as the substituting medium instead of the acetone in our FSM (FSM B).

3) RNA are well stained and localized in the liver cells. Pyronine-methylgreen after FSM A.

4) RNA are poorly stained and capriciously localized. Pyronine-methylgreen staining after FSM B.

5) Alkaline-phosphatase shows a remarkable reaction in the bile-capillaries as the striated form. Gomori's method after FSM A.

6) Alkaline-phosphatase shows no reaction in the liver tissue. Gomori's method after FSM B.

7) RNA are well localized but poorly stained in the liver cells. Pyronine-methylgreen staining after the Philips' FSM.

8) Alkaline-phosphatase shows no reaction in the liver tissue. Gomori's method after Philips' FSM.

\section{Studies on Freeze-Substitution Method in Histochemistry (III) Observations on Secretory Granules of Salivary and Some Other Glands.}

\author{
Akitoshi Sugimoto, Toshio Yagi, Masanao Takahashi, \\ Kinji Oкамотo, Fusazo Taguchi, Kazuo Sakamoto \\ and Haruo Hiraoka. \\ Dept. of Oral Pathology, Osaka University Dental School, Osaka, Japan.
}

In the freeze-substitution method for histochemical preparation of the tissue section, an alternative technique was introduced by Lison ${ }^{11}$ and later improved by Feder $\&$ Sidman $^{2}$. It was based on adding some fixatives to the substitution medium in which tissue blocks were dehydrated at lower temperature. Some modifications of this method and their results have been published by us also (Sugimoto \& Yagi ${ }^{3)}$ ). The present paper is concerned with further investigations on other modifications suitable for fixation of mucopolysaccharides or mucoproteins and on their application to the secrtory granules of salivary and some other glandular tissues in rats. 